\title{
Environmental Knowledge, Ecosystem and Attitude Toward Environmentally Friendly Behavior for Coastal Community
}

\author{
Salma Samputri ${ }^{1 *}$, Dian Safitri ${ }^{2}$
}

\author{
${ }^{1}$ Universitas Negeri Makassar, INDONESIA \\ ${ }^{2}$ Universitas Muhammadiyah Makassar, INDONESIA \\ *Corresponding Author: salmasamputri@unm.ac.id
}

Citation: Samputri, S., \& Safitri, D. (2020). Environmental Knowledge, Ecosystem and Attitude Toward Environmentally Friendly Behavior for Coastal Community. Aquademia, 4(2), ep20027. https://doi.org/10.29333/aquademia/8580

ARTICLE INFO

Received: 25 Jun. 2020

Accepted: 13 Aug. 2020

\begin{abstract}
This research was a survey research by using quantitative approach, where the instrument was environmental acquaintance test and questionnaire. The research was conducted in coastal area in Makassar such as: Biringkanaya district (Untia urban village), Tamalate district (Barombong urban village), Ujung Tanah district (Cambayya urban village). The population of this research was the coastal communities in Makassar who work as fishermen for generations. The result indicated that there were influences between environmental knowledge, knowledge about ecosystem, knowledge about pollution and environmental attitude with environmentally friendly behavior. The sample of this research was 150 head of households. The result showed that the environmental knowledge of coastal community in Makassar was in medium category. Knowledge about pollution was categorized as medium, environmentally friendly behavior was in medium category and so does environementally friendly behavior were in medium category.
\end{abstract}

Keywords: environment, ecosystem, behavior, knowledge

\section{INTRODUCTION}

Environmental issues have become crucial recently. This is due to ecological damage caused by carbon emissions through industrialization activities in severalcountries causing high rates of increase in global temperature or commonly known as global warming in the past few years. There are some environmental issues in the 21st century that have been addressed in UNEP (United Nations Environmental Program). As found in the journal entitled "UNEP Foresight Process on Emerging Environmental Issues". In those 21 issues, there are some strategic issues about the coastal environment, they are: Catalyzing Rapid and Transformative Changes in Human Behaviour towards the Environment, Coastal Ecosystems: Addressing Increasing Pressures with Adaptive Governance and Potential Collapse of Oceanic Systems Requires Integrated Ocean Governance (UNEP, 2012).

Environmental damage can occur due to the activities carried out by humans and due to the influence of nature. One of the side effects of development activities in coastal areas is the presence of ambient waste, increasing waste, both in quantity and type by the growth of the community in the area. The waste has caused pollution that damages environmental functions (Tandjung, 1991). environmental attitude has a dominant influence on the decision to adopt conservation (Sugandini, Rahatmawati, \& Arundati, 2018).

Based on preliminary observations in the field, it is found that the low quality of human resources does not only occur in coastal communities but also human resources, this is closely related to the low level of community education, both formal and non-formal education. The consequences as a result of the low quality of human resources cause the following: natural resources in coastal areas can not be used optimally; the use of natural resources without regard to aspects of environmental sustainability; the mastery of technology in the use of coastal resources is still low; active community participation in the management of coastal areas is still low; and environmental sanitation in coastal areas is still poor (Panjaitan, 2007).

Several human activities are known to have the potential to cause environmental damage to coastal and marine areas. These human activities can be grouped into several types, such as settlement, agriculture, fisheries, industry, tourism (maritime) sea transportation (port), mining, and energy. These activities have produced direct and indirect negative impacts. The direct impact is direct damage to the ecosystem of natural resources in coastal areas, for example, fishing using explosives, dredging the bottom of the shipping channel, dumping anchors in boats in coral areas, taking reefs for building materials. While the indirect impact is the waste of production leftovers that are disposed of in the coastal area. 
These wastes can pollute the environment of natural resources, especially biodiversity in coastal areas (Supriharyono, 2001).

Another problem with coastal areas is the biophysical degradation of the coastal environment. The mangrove ecosystem is a habitat for various types of fish, crabs, shrimp, shellfish, reptiles, and mammals. Detritus from mangrove is the base of the food chain's formation for a lot of organisms in the coastal and in the sea. The decreasing width of mangrove forest from year to year and the impact existed now. The main factor of the mangrove decreasing was (1) mangrove area conversion to shrimp farming; (2) unprofessional friendly aquaculture/pond management; (3) there is no clear policy related to land tenure and coastal conservation in the village; (4) the community less awareness about the importance of preservation and low of the social-economic condition of a community in mangrove area. Furthermore, the deforestation of mangrove on a large scale has an impact on the decline in the mangrove vegetation; decreased water quality, especially increased sedimentation which harms coral reef life; decreased catches, especially crabs, shellfish and shrimp (Panjaitan, 2007).

Water pollution is a change in conditions in lakes, rivers, oceans, and groundwater due to human activity. In everyday life, people need clean water for drinking, cooking, washing, and other needs. Clean water must have colorless, smelly, and poisonous standards. Water pollution is a distortion of the properties of water from the normal state not of its purity. Much fresh water is heavily polluted by the remnants of sewage and liquid waste from household and industrial wastes into rivers (Kollmus \& Agyeman, 2006).

According to Solihin and Darsati (1993) water pollution can be classified into 3 groups, namely: Chemical pollution, in the form of carbon compounds and inorganic compounds, Physical pollution, in the form of floating material and suspended material, and biological pollution, in the form of pathogenic microbes, mosses, and aquatic plants. The definition of water pollution according to the Decree of the Ministry of Country Population and Environment Number KEP-02 / MENKLH / 1998 concerning the stipulation of environmental books is the entry or inclusion of living things, substances, energy and or other components into the water and or changes in the order of water by natural processes, so that water quality drops to a certain level causing the water to become less or no longer functioning.

Makassar City which has coastal waters is inseparable from the problems of the coastal environment. Makassar City Regional Regulation No. 6 of 2006 concerning the Makassar City Regional Spatial Plan 2005-2015, which confirms that the Makassar City coastal area is included in the development area, with the basic policy directed at improving tourism activities, the quality of life of fishing communities through enhancing marine cultivation and utilization of fisheries resources by conserving coral reef ecosystems. While no specific rules are governing the coastal areas of Makassar City, they are still based on national regulations.

Monoarfa (2002) stated that the cause of the decline in the quality of the waters of Makassar City is suspected from the results of the study of three dominant sources, they are the concentration of population in the city, industrial activities around Makassar City and agricultural activities in the upstream of the Jeneberang and Tallo rivers. Centralized urban population generates considerable waste, both solid and liquid waste. The waste enters the Makassar coastal waters and results in shallowing beaches and changes in water quality parameters such as DO content, BOD values, COD values, and the emergence of toxic compounds and eutrophication.

From the description of the environmental quality problems of the coastal and marine areas, it cannot be separated from the behavior of the community, both in carrying out their activities as fishermen, workers or entrepreneurs, as well as residents of coastal space. With environmental behavior, it is expected that the quality of the environment will also improve. However, many factors influence environmental behavior, such as knowledge about the environment, knowledge about ecosystems, knowledge about pollution, motivation, attitudes in maintaining and preserving the environment, and other factors such as environmental situations and conditions.

\section{METHODOLOGY}

This research used a survey method with a quantitative approach. The research was conducted in the coastal area in Makassar such as Biringkanaya district (Untia urban village), Tamalate district (Barombongurban village), Ujung Tanah district (Cambayya urban village). The population of this research was the coastal communities in Makassar. Sugiyono (2011) argued that Population is a generalization area that consists of objects and subjects that have certain qualities and characteristics set by researchers to be studied and then draw conclusions. Along with the theory explained above, the population includes the characteristics or attitudes owned by the subject or object in the study. The research sample consisted of 150 heads of households who lived in the coastal areas of Tamalate, Untia and Cambayya sub-districts, Makassar City, South Sulawesi.

The instrument used in this research was the environmental knowledge test with $0-1$ score. The correct answer was given 1 while the wrong answer was given 0 . Knowledge about ecosystem test with $0-1$ score. The correct answer was given 1 while the wrong answer was given 0 . Environmental attitude test with 0-1 score. The correct answer was given 1 while the wrong answer was given 0 . Environmentally friendly behavior test with 0-1 score. The correct answer was given 1 while the wrong answer was given 0 . Question or statement of scale for Likert model attitude and developed based on research objectives, with a score of $1-5$. Namely: strongly agree, agree, neither agree nor disagree, disagree, and strongly disagree. Behavioral scale questions or statements, with a score of 1 - 5 on each item, namely Always, often, sometimes, rarely, and never. 
Table 1. Frequency Distribution of Makassar Coastal Communities' Environmental Knowledge

\begin{tabular}{ccccccccc}
\hline No. & \multicolumn{2}{c}{ Interval Data } & Category & Frequency & Percentage & \multicolumn{2}{c}{ Valid Percentage Cumulative Percentage } \\
\hline 1 & 0 & - & 14 & Low & 0.00 & 0.00 & 0.00 & 0.00 \\
\hline 2 & 15 & - & 28 & High & 150.00 & 100.00 & 100.00 & 100.00 \\
\hline & & & Total & 200.00 & 100.00 & 100.00 & \\
\hline
\end{tabular}

Table 2. Frequency Distribution of Makassar Coastal Communities' Ecosystem Knowledge

\begin{tabular}{|c|c|c|c|c|c|c|c|c|}
\hline No. & \multicolumn{3}{|c|}{ Interval Data } & Category & Frequency & Percentage & Valid Percentage & Cumulative Percentage \\
\hline 1 & 0 & - & 13 & Low & 0.00 & 0.00 & 0.00 & 0.00 \\
\hline \multirow[t]{2}{*}{2} & 14 & - & 25 & High & 150.00 & 100.00 & 100.00 & 100.00 \\
\hline & & & & Total & 200.00 & 100.00 & 100.00 & \\
\hline
\end{tabular}

Table 3. Frequency Distribution of Makassar Coastal Communities' Pollution Knowledge

\begin{tabular}{ccccccccc}
\hline No. & \multicolumn{2}{c}{ Interval Data } & Category & Frequency & Percentage & \multicolumn{2}{c}{ Valid Percentage Cumulative Percentage } \\
\hline 1 & 0 & - & 13 & Low & 0.00 & 0.00 & 0.00 & 0.00 \\
\hline 2 & 14 & - & 26 & High & 150.00 & 100.00 & 100.00 & 100.00 \\
\hline & & & Total & 200.00 & 100.00 & 100.00 & \\
\hline
\end{tabular}

Table 4. Frequency Distribution of Makassar Coastal Communities' Environmental Attitude

\begin{tabular}{ccccccc}
\hline No. & Interval Data & Category & Frequency & Percentage & Valid Percentage Cumulative Percentage \\
\hline 1 & $24-43$ & Very low & 0.00 & 0.00 & 0.00 & 0.00 \\
\hline 2 & $44-62$ & Low & 0.00 & 0.00 & 0.00 & 0.00 \\
\hline 3 & $63-81$ & Medium & 2.00 & 1.30 & 1.30 & 7.30 \\
\hline 4 & $82-100$ & High & 112.00 & 74.70 & 74.70 & 76.00 \\
\hline 5 & $101-120$ & Very high & 36.00 & 24.00 & 24.00 & 100.00 \\
\hline & Total & 150.00 & 100.00 & 100.00 & \\
\hline
\end{tabular}

\section{RESULT}

\section{Description of Environmental Knowledge}

Respondent data based on the variable Environmental knowledge of the coastal city of Makassar can be seen in Table 1.

Based on the results of the analysis above it is indicated that the condition of environmental knowledge of the coastal city of Makassar in the low category obtained a percentage of $0.00 \%$ and in the high category obtained a percentage of $100 \%$ or 150 of 150 total respondents. From these results, it can be concluded that the majority of respondents are at data intervals of 14-100 with a high category.

\section{Description of Ecosystem Knowledge}

Respondent data based on the variable knowledge of the Makassar coastal community ecosystem can be seen in Table 2.

Based on the results of the analysis above it is indicated that the condition of ecosystem knowledge of the coastal city of Makassar in the very low category obtained a percentage of $0.00 \%$, in the low category a percentage of $0.00 \%$ was obtained and in the high category a percentage of $100 \%$ or 150 of 150 total respondents was obtained. From these results it can be concluded that the majority of respondents are in the data interval 13 - 25 with a high category.

\section{Description of Pollution Knowledge}

Respondent data based on the variable Knowledge of pollution in the coastal city of Makassar can be seen in Table 3.
Based on the results of the analysis above it is indicated that the condition of pollution knowledge of the coastal city of Makassar in the very low category obtained a percentage of $0.00 \%$, in the low category a percentage of $0.00 \%$ was obtained and in the high category a percentage of $100 \%$ or 150 of 150 total respondents was obtained. From these results it can be concluded that the majority of respondents are in the data interval 13 - 26 with a high category.

\section{Description of Environmental Attitude}

Respondent data based on the attitudes of the Makassar coastal community can be seen in Table 4 .

Based on the results of the analysis above it can be indicated that the condition of the environmentally friendly behavior of the Makassar coastal community in the category is very low with a percentage of $0.00 \%$, in the low category and the percentage is $0.00 \%$, in the medium category, the percentage is $1.30 \%$ or 2 out of 200 total respondents, in the high category the percentage is $74.70 \%$ or 112 of 200 total respondents and in the very high category, the percentage is $24.00 \%$ or 24 out of 200 total respondents. From these results, it can be concluded that the majority of respondents are in the data interval 82-100 with a high category.

\section{Description of Environmentally Friendly Behavior}

Respondent data based on environmentally friendly behavior of the coastal city of Makassar can be seen in Table 5.

Based on the results of the analysis above, the condition of environmentally friendly behavior of the Makassar coastal community is in the very low category with a percentage of $0.00 \%$, in the medium category, the percentage is $6.70 \%$ or 10 out of 200 total respondents, in the high category, the 
Table 5. Frequency Distribution of Makassar Coastal Communities’ Environmental Attitude

\begin{tabular}{ccccccc}
\hline No. & Interval Data & Category & Frequency & Percentage & \multicolumn{2}{c}{ Valid Percentage Cumulative Percentage } \\
\hline 1 & $24-43$ & Very low & 0.00 & 0.00 & 0.00 & 0.00 \\
\hline 2 & $44-62$ & Low & 0.00 & 0.00 & 0.00 & 0.00 \\
\hline 3 & $63-81$ & Medium & 10.00 & 6.70 & 6.70 & 78.00 \\
\hline 4 & $82-100$ & High & 117.00 & 78.00 & 15.30 & 100 \\
\hline 5 & $101-120$ & Very high & 23.00 & 15.30 & 100 & \\
\hline & Total & 150 & 100 & & \\
\hline
\end{tabular}

percentage is $78.00 \%$ or 117 out of 200 total respondents and in the very high category, the percentage is $15.30 \%$ or 23 out of 200 total respondents. From these results it can be concluded that the majority of respondents are at data intervals of 82-100 with a high category.

\section{Environmental Knowledge}

Environmental Knowledge Coastal communities in Makassar City which were included in the medium category were found in Untia urban village, Barombong urban village, and Cambayya urban village. The environmental knowledge referred to in this study are: (i) Factual: concepts and patterns of life of coastal communities, the influence of local wisdom on the management of coastal areas, potential damage to coastal areas; (ii) Conceptual: the relationship between humans and the environment, coastal resources, protection of mangrove areas, the concept of tradition and local wisdom towards the patterns of life and habits of coastal communities; (iii) Procedures: management of coastal areas, coastal reclamation, construction of buildings, and fishing methods.

The main factors affecting the knowledge of coastal communities included in the medium category are caused by income or poverty levels and education. Poverty is a major factor in the low level of education of fishermen that the level of their knowledge of the surrounding environment is quite adequate. One of the main factors in poverty is non-natural factors as conceived by Kusnadi (2002). Factually, one of the factors that cause poverty in fishing communities is nonnatural factors related to the limitations of the reach of the sea area that is so broad and it contains a variety of potential resources. If optimally utilized and preserved, it will become a source of future livelihood for the community. Furthermore, it is said that fishermen who are sometimes positioned only as workers at sea are considered not to have significant knowledge to contribute to the empowerment of the nation. Various doubts about the ability of fishermen who are actually not owned by other communities. Even though the specific ability of these fishermen is a cooperative advantage owned by this nation. Therefore, fishermen can actually be the main trigger in the efforts to achieve the success of fisheries and marine development.

In addition, a factor influencing the lack of environmental knowledge in coastal communities is the fishermen's belief system. Their knowledge systems are still related to mythology, ritualization, culture, and magic (ritual and magical behavior), especially those relating to social ecological systems related to the fishing world. In fact, in situations where fishermen face severe obstacles or serious situations, such as when waves and big storms come to hit their boats, then acts of metaphysical manipulation are often done to tame the marine world (Arifin, 1991). So, the scientific aspects are sometimes ignored and prioritize the cultural system because fishermen know the system better. Activities that might affect the environmental attitudes and behaviors (practical and interrelated activities based on natural environment, projects, group work, discussions, case studies, audio and visual simulations, brain storming, etc) should be involved more than theoretical knowledge (Sadik \& Sadik, 2014).

\section{Ecosystem Knowledge}

The knowledge of ecosystems owned by coastal communities in Makassar City in the Untia, Barombong and Cambayya Villages is in the medium category. Where in the three villages there are residents whose educational backgrounds are at elementary, junior high and high school levels. The ecosystem knowledge referred to in this study is: (i) Factual: the concept of mangrove areas, and potential damage to coastal areas; (ii) Conceptual: the conservation of coastal areas, infrastructure of coastal settlements and the relationship between biotic and abiotic components in coastal areas; (iii) Procedural: efforts to prevent damage to coastal areas, waste management in preserving coastal areas, the role of the community and the government in the preservation of coastal areas.

Tohir (2001) argues that there is an interesting phenomenon regarding the abundance of marine natural resources with the low interest of the fishing community to explore the richness of the sea. This is caused by a lack of or sufficient knowledge of the marine ecosystem.

This is in line with research conducted by Mulyadi (2011) on the knowledge of coastal communities about mangrove ecosystems. Preservation of mangroves in the community at this time is lacking, this is due to lack of understanding of the importance of the benefits of mangroves. The community awareness-raising program about community-based mangrove conservation is one way to provide understanding and knowledge to the community that mangroves have many uses and benefits for humans. These benefits can be felt by planting and maintaining. The ability and public awareness to manage and preserve mangroves have already exists, but the attention of many parties is lacking such as the Government and Higher Education in seeing this potential. Therefore, it is necessary to have cooperation between the Government and Higher Education in managing mangrove with a broad scope.

\section{Pollution Knowledge}

Pollution Knowledge from Coastal Communities in Makassar City which is in the medium category is found in Untia, Barombong and Cambayya. Where the educational background of the community in the three villages are at elementary, junior high and high school levels. The pollution knowledge are (i) Factual: methods of disposal of household 
and industrial waste for coastal communities, coastal environmental sanitation conditions, the influence of coastal recreation or tourism development on potential pollution in coastal areas, and exploitation of coral reefs; (ii) Conceptual: general description of environmental pollution, types of waste, decomposition of organic waste, and the quality of fish and other coastal resources due to polluted seas; (iii) Procedural: preventive efforts in environmental management, use of fish bombs in coastal areas, mangrove planting along coastal areas, and land use management in coastal areas. Pollution knowledge is strongly influenced by how much the level of community knowledge on the effects of activities that occur at sea, for example: garbage. The knowledge of pollution in this research is moderate. This is also consistent with Salim's research (2014), which states that based on the results of the FGD, the Pare-Pare City Coastal Communities have carried out waste disposal activities, but the volume of waste dumps is high, making it difficult for the community to clean them. Whereas for example used oil, people do not have the ability to clean it. From this aspect, it indicates that the coastal communities of the city of Pare-Pare essentially have a high initiative towards the management of pollutant waste at sea but knowledge of the pollution that is causing the waste to be managed as it is. Even this is in line with the ideas of Dahuri (2001) about common problems in coastal areas. As for the problems such as: pollution, damage to coastal habitats, and overuse of resources. Knowledge of pollution that is not qualified will affect the quality of the environment in coastal areas.

\section{Attitude to Maintain Coastal Environment}

The attitude of maintaining the coastal environment of the Coastal Communities that are in the neutral category in Makassar City is found in Untia, Barombong and Cambayya. Where in the three villages the educational background of the community at the elementary, junior high and high school levels. The attitude of maintaining in this research are: (i) Cognitive: dispose of waste in its place will preserve the environment, maintain and manage coastal areas, and manage waste properly will create a healthy environment. (ii) Affective: mutual cooperation in environmental conservation, stewardship of coastal land will improve the environment, not cutting down mangroves, improving environmental health by disposing and managing waste and waste in its place.

The attitude of maintaining a coastal environment that is classified as a medium is in line with research conducted by Mashuri (2012) in Untia Makassar District. Attitudes or behaviors to preserve the environment by the fishermen are in the medium category or around $46.15 \%$. Furthermore, Rapi (2008) at the Islamic High School of the Islamic Boarding School Ummul Mukminin, Makassar. The students in the high school have an attitude of caring for the environment by looking at the percentage of students who have a positive attitude towards the environment by $57.14 \%$.

\section{Environmentally Friendly Behaviour of Coastal Community}

The behavior of environmentally friendly of coastal communities in Makassar City which is in the neutral category is found in Untia, Barombong and Cambayya. Where in the three subdistrict, the background behind the education of the community is the elementary, junior high and high school levels. The environmental behavior of coastal communities in this study are: (i) behavior to prevent environmental impacts: proper waste and waste management, tree planting for environmental balance, mutual care and mutual cooperation in preserving the environment, and management of marine products quality; (ii) Environmental preservation behavior, in the form of: environmentally based fishing methods, utilization of borders on the beach, and provision of Green Space in environmental conservation; (iii) Environmentally Friendly Behavior: Manufacture and Establishment of Waste Management Installation, management of coral reefs, empowerment of coastal areas as tourist areas, and training and counseling on management of coastal areas and resources.

People who live in coastal areas have their own characteristics. Based on the results of the study, the environmentally friendly behavior of coastal communities is included in the moderate category. This is in line with the characteristics of coastal communities according to Kusnadi (2003), where people on the coast are generally traditional fishermen with low family incomes that have an impact on the availability of family food, and the availability of decent and healthy homes. Home for fishermen is mostly just a stopover. Nearly half of the lives of fishermen are spent at sea so that concern for a healthy home is considered relatively moderate, as well as health behaviors such as bowel habits. Most people defecate on the beach.

Natoatmodjo (2006) in his entity confirmed that where the social factors that influence health behavior are selfperception. Selfconcept is satisfaction or dissatisfaction felt by an individual, and group image, where the group's perception in a community about health behavior will be emulated or will be followed by other community members.

Manumono (2008), The behavior of coastal communities can be internal or external and can be positive or negative. Intern in the sense of daily behavior that involves oneself such as apathy, a priori, traumatic and others. Whereas external is daily behavior that involves other people both within the family and outside the family such as cooperation, paternalism and others. As a result of low income or low level of welfare causes changes in community behavior.

\section{CONCLUSION}

Based on the results of the study concluded that the environmental knowledge of coastal communities in the city of Makassar is included in the medium category that is 85 respondents (57\%). Knowledge of the ecosystems of the coastal city of Makassar is included in the medium category with 74 respondents (49\%). Knowledge of pollution in the Makassar coastal city community is included in the moderate category of 73 respondents (49\%). Attitudes to Care for the Environment in the Coastal Areas of Makassar City are still in the moderate category of 81 respondents (54\%). Environmentally friendly behavior in Makassar City is included in the moderate category with 86 respondents (57\%). 


\section{REFERENCES}

Arifin, Z. (1991). Evaluasi Insruksional Prinsip-prinsip TeknikProsedur. Bandung: PT. Remaja Rosdakarya.

Dahuri, R. (2004). Sumber Daya Wilayah Pesisir dan Lautan Secara Terpadu, Jakarta: PT. Pradnya Paramita.

Kollmuss, A., \& Agyeman, J. (2006). Mind the Gap: Why do people act environmentally and what are the barriers to pro-environmental behavior. Environmental Education Research, 8, 239-260. https://doi.org/10.1080/1350462022 0145401

Kusnadi. (2003). Akar Kemiskinan Nelayan. Yogyakarta: LKIS.

Manumono, D. (2008). Perubahan Perilaku Masyarakat Pesisir Akibat Penurunan Pendapatan Sebagai Dampak Abrasi dan Rob di Demak. Departemen Pertanian.

Mashuri. (2012). Analisis Perilaku Melestarikan Lingkungan Hidup Nelayan di Desa Nelayan Kelurahan Untia Kecamatan Biringkanaya Kota Makassar. Makassar: Program Pascasarjana Universitas Negeri Makassar.

Monoarfa, W. (2002). Dampak Pembangunan Bagi Kualitas Air di Kawasan Pesisir Pantai Losari Makasar. Jurnal Science \& Teknologi, 3(3), 37-44.

Mulyadi. (2011). Effect of Environmental Knowledge, Local Wisdom, Locus of Control and Farming Motivation on Responsible Environmental Behavior of Farmers in Soppeng Regency of South Sulawesi. International Journal of Academic Research, 3(2), 98-104.

Notoatmodjo, S. (2006). Pengembangan Sumber Daya Manusia. Jakarta: Rineka Cipta.

Panjaitan, P. (2007). Pengelolaan Terumbu Karang Berbasis Masyarakat. VISI, 15(3), 273-288.
Rapi. (2008). Perilaku Santri Terhadap Lingkungan Hidup. Makassar: Program Pascasarjana Universitas Negeri Makassar.

Sadik, F., \& Sadik, S. (2014). A study on environmental knowledge and attitudes of teacher candidates. Procedia Social and Behavioral Sciences, 116(2014), 2379-2385. https://doi.org/10.1016/j.sbspro.2014.01.577

Salim, A. (2014). Perilaku Ekologis (Eco Behavior) Dalam Penatagunaan Lahan Kawasan Pesisir Kota Pare-Pare. Makassar: Program Pascasarjana Universitas Negeri Makassar.

Solihin, \& Darsati, S. (1993). Air. Jurusan Pendidikan FPMIPA, IKIP Bandung.

Sugandini, D., Rahatmawati, I., \& Arundati, R. (2018). Environmental Attitude on the Adoption Decision Mangrove Conservation: An Empirical Study on Communities in Special Region of Yogyakarta, Indonesia. Review of Integrative Business and Economics Research, 7(1), 266-275.

Sugiyono. (2011). Statistik untuk Penelitian. Bandung: Alphabeta.

Supriharyono. (2001). Potensi dan Perusakan Sumber Daya Terumbu Karang, Serta Upaya Pengelaannya di Indonesia, Pidato Pengukuhan Guru Besar Universitas Diponegoro, Semarang.

Tandjung, S. D. (1991). Konservasi Sumber Daya Alam. Fakultas Biologi Universitas Gadjah Mada Yogyakarta.

Tohir, K. 2001. Seuntai Pengetahuan Tani. Jakarta: PT. Rineka Cipta.

UNEP. (2012). UNEP Foresight Process on Emerging Environmental Issues. UNEP Publication. 